\title{
Cost-benefit analysis of farm water storage: Surface Storage versus Managed Aquifer Storage
}

\author{
M. Arshad, $^{\text {a,b }}$, M.E. Qureshi ${ }^{\text {c }}$ and A.J. Jakeman ${ }^{\text {a,b }}$ \\ ${ }^{a} i C A M$, The Fenner School of Environment and Society, \\ The Australian National University Canberra, ACT 0200, Australia. \\ ${ }^{b}$ National Centre for Groundwater Research and Training (NCGRT), Canberra. \\ ${ }^{c}$ CSIRO Ecosystem Sciences, Black Mountain, ACT, GPO Box 1700 \\ Email: Muhammad.arshad@anu.edu.au
}

\begin{abstract}
Managed Aquifer Recharge (MAR) has been demonstrated to offset groundwater demand in many locations around the world. At each location where MAR has been successfully undertaken, there are unique hydro-climatic, socio-economic and institutional conditions. This has resulted in a variety of methods to recharge aquifers. Despite its physical potential, there has been limited uptake of MAR in Australia. Limited knowledge of the actual costs and benefits from MAR projects is a major barrier to the uptake of MAR. The cost of an MAR scheme is highly variable across regions because of several hydrogeological and climatic influencing factors, such as the rate of recharge, type of aquifer, water source, water quality and method of water treatment. The comparative cost of MAR with regard to surface water storages is poorly known in Australia. Published MAR cost estimates are local and situation specific, making cost comparison difficult across regions. The aim of this paper is to estimate the economic efficiency of using stored water in surface dams to that stored in an aquifer using MAR. The study estimates, for the Lower Namoi cotton irrigation district in New South Wales, Australia, the relevant costs and benefits and compares net irrigation benefits under three different water storage methods - surface storage in farm dams, aquifer storage using pond infiltration and aquifer storage using injection wells. Preliminary results indicate that aquifer storage is financially viable. But the maximum cost of aquifer storage, regardless of MAR method, should not exceed $500 \$ / \mathrm{ML}$ to achieve the breakeven point, that is the point at which the cost of aquifer storage is equal to the resulting farm benefits. Sensitivity analysis is performed on key variables such as the infiltration rates, costs of pumping and cotton prices. Infiltration rates and pumping costs are found less sensitive, while cotton price was, not surprisingly, found highly sensitive to the NPV. A $50 \%$ reduction in infiltration rates and a $25 \%$ increase in the cost of pumping does not significantly affect the NPV. However, a $10 \%$ and $25 \%$ reduction in the price of cotton renders a $27 \%$ and $78 \%$ reduction in the NPV, respectively.
\end{abstract}

Keywords: Groundwater, managed aquifer recharge, cost-benefit analysis 
Arshad et al. 2013, Cost-Benefit Analysis of Farm Water Storage: Surface Storage versus Managed Aquifer Storage

\section{INTRODUCTION}

Across Australia, overdraft from aquifers is resulting in falling groundwater levels in the shallow, unconfined systems and decreasing groundwater pressures in the deep confined and semi-confined systems (MDBA, 2012). In response to the groundwater overdraft, the New South Wales (NSW) government has reduced current groundwater entitlements in the stressed aquifer systems (Smithson, 2009). For the lower Namoi, a highly developed cotton irrigation district in NSW, this cutback translates to a reduction of 21 gigalitre (GL)/year in groundwater entitlements for irrigation by 2015 and beyond. Groundwater in the Namoi River Catchment supports an irrigation industry worth in excess of AU\$380 million per annum (Namoi CMA, 2013). All irrigation water is stored and routed from surface storages before application to the field. On-farm water storages within the lower Namoi range from conventional single cell to advanced multi cell farm dams. The typical Namoi valley farm holds enough water in storage to complete one full year of irrigation. Conservative estimates suggest that the total capacity of on-farm storages in the cotton industry could be in the order of 3150 gigalitre (GL). Evaporative losses from these surface storages are significant. On average from surface water storages, evaporative losses range between 1200 to $1800 \mathrm{~mm} / \mathrm{yr}$ (Wigginton, 2011), which constitute approximately $35 \%$ to $50 \%$ of farm storage losses.

To tackle the twin problem of reduced allocation and evaporative losses, improving water use efficiency at the farm level is an obvious option. This will include installing spray or trickle irrigation systems, lining water courses and further improving the design of surface storages to minimize evaporative and seepage losses. Improving water use efficiency needs to be a stepwise approach, however, and will involve significant time and monetary resources to achieve the desired goal. Another potential option to tackle the stated twin problems is to store water underground in aquifers using Managed Aquifer Recharge (MAR). The MAR can serve the purpose of increasing groundwater storage in wet periods in order to support agricultural and environmental use of water during dry periods. Recently, several studies have highlighted the potential of a regional-scale MAR project in the lower Namoi. These studies have mainly contributed to the hydrologic, hydrogeological and social aspects of MAR. Arshad et al. (2012) indicated that, on average, about $85 \mathrm{GL}$ of flood water could be available annually under the current rules in the lower Namoi. A significant volume of water could be available for MAR while satisfying environmental flow and ecological requirements. Similarly, Rawluk et al. (2012) highlighted a high level of social acceptability for an MAR project in the study area.

Against the background of addressing reduced water availability and evaporative losses, aquifer storage via MAR in the lower Namoi provides an opportunity to minimize evaporative losses that would otherwise occur from surface storages. This paper evaluates the financial viability of aquifer recharge and storage in the lower Namoi irrigation district. This will give farmers a financial comparison and resultant change in farm income between storing water underground and that of storing it in surface dams. Though assessment of the associated environmental costs, benefits and risks is an important and related research topic, it is beyond the scope of this paper.

\section{THE CONCEPTUAL ANALYTICAL FRAMEWORK}

The study undertakes an analysis to estimate irrigation related costs and benefits for a hypothetical irrigation farm over the next 50 years. The analysis considers a cotton irrigation farm which has three different water storage and management options in the lower Namoi. Only less than $20 \%$ of the available land is irrigated due to limited water availability, thus irrigated land in each year is variable. Irrigated $\operatorname{cotton}^{1} \mathrm{Bt}$ (Bacillus thuringiensis) and faba bean (Vicia faba L) are the sustainable summer and winter rotations that provide the highest net income per megalitre (ML) of irrigation water applied. Dryland farming with winter wheat, chick pea and faba bean is carried out on marginal lands and also on paddocks that remain uncultivated by irrigation water. It is assumed in the analysis that all required irrigation infrastructure, such as surface storage and irrigation water delivery network, are already built for the entire irrigation land, given that it is a common practice in the study area. Annual water availability for the analysis is considered to be $1350 \mathrm{ML}$ based on recent irrigation water allocations in the lower Namoi ${ }^{2}$. Farm economic data, such as variable cost of farm inputs, cotton prices and gross margins from irrigated and dryland, are adopted from Powell and Scott (2011) and NSW Department of Primary Industries (2013), shown in Table 1.

${ }^{1}$ Pigeon pea is planted as a refuge/sacrificial crop for pest control with irrigated cotton on about $5 \%$ of the cotton area. This replaces the need of pesticide use. Gross margins per ha and per ML of the cotton crop have been adjusted in relation to the refuge crop. Gross Margin for pigeon pea is estimated as $-\$ 75 / \mathrm{ML}$ or $-\$ 456 / \mathrm{ha}$. Gross Margin for pigeon pea is negative as the cost of input is considered without any direct harvesting benefits of the crop. The benefits of pigeon pea plantation are accounted for in the increased cotton yield.

${ }^{2}$ The model considers $400 \mathrm{ML}$ of regulated surface water ( $25 \%$ allocation of the average $1600 \mathrm{ML}$ ) plus $200 \mathrm{ML}$ of the surface water through supplementary access ( $25 \%$ allocation of the average $800 \mathrm{ML}$ ) and $750 \mathrm{ML}$ of groundwater ( $100 \%$ allocation) from both aquifer access and supplementary licences. 
Arshad et al. 2013, Cost-Benefit Analysis of Farm Water Storage: Surface Storage versus Managed Aquifer Storage

Table 1. Gross margins and net farm income, irrigated and Dryland

\begin{tabular}{|l|l|l|l|l|l|l|l|l|l|}
\hline \multicolumn{1}{|c|}{ Crop } & $\begin{array}{c}\text { Irrigation } \\
\text { Water Use } \\
\text { ML/ha }\end{array}$ & $\begin{array}{c}\text { Yield } \\
* \text { bales/ha } \\
\text { Tonnes/ha }\end{array}$ & $\begin{array}{c}\text { Price } \\
* \$ / \text { bale } \\
\$ / \text { Tonne }\end{array}$ & $\begin{array}{c}\text { Gross } \\
\text { Value } \\
* / \text { bale } \\
\$ / \text { Tonne }\end{array}$ & $\begin{array}{c}\text { Variable } \\
\text { Cost } \\
\$ / \text { ha }\end{array}$ & $\begin{array}{c}\text { Gross } \\
\text { Margin } \\
\$ / \text { ha }\end{array}$ & $\begin{array}{c}\text { Gross } \\
\text { Margin } \\
\$ / \mathrm{ML}\end{array}$ & $\begin{array}{c}\text { Net } \\
\text { Income } \\
\$ / \text { ML } \\
\# / \text { ha }\end{array}$ & $\begin{array}{c}\text { Net } \\
\text { Contribution } \\
\text { in Farm } \\
\text { Income } \\
\%\end{array}$ \\
\hline $\begin{array}{l}\text { Irrigated Cotton } \\
\text { Bt) }\end{array}$ & 7.9 & $9.5 *$ & $538^{*}$ & $5,111^{*}$ & 2,505 & 2,606 & 326 & 207 & 57 \\
\hline $\begin{array}{l}\text { Irrigated Faba } \\
\text { Bean }\end{array}$ & 2.7 & 5.0 & 348 & 1,740 & 565 & 1,175 & 435 & 277 & 28 \\
\hline $\begin{array}{l}\text { Dryland, Wheat } \\
\text { and Faba Bean }\end{array}$ & & 1.6 & 296 & 474 & 225 & 249 & & $158^{\#}$ & 15 \\
\hline
\end{tabular}

Data Source: Powel and Scott, 2011 and DPI, NSW 2013

* Cotton, price is in \$/bale including both lint and seed
${ }^{\#}$ net income for dryland is in \$/ha

\section{SUITABILITY AND COST OF AQUIFER STORAGE}

For basin infiltration systems, aquifers should be unconfined and sufficiently transmissive to accommodate lateral flow of the infiltrated water without forming high groundwater mounds. Where sufficiently permeable soils and/or sufficient land areas for surface infiltration systems are not available, groundwater recharge can be achieved with vertical infiltration systems, such as trenches, infiltration galleries and through hand dug wells in the unsaturated zone. Basin infiltration can be highly effective and cheaper than injection wells boreholes in areas where river-aquifer connectivity exists. These basin infiltrating recharge methods are relatively inexpensive compared to ASR methods.

The costs of an aquifer storage facility include the capital, operating and maintenance cost of water recharge, storage and recovery infrastructure, such as an infiltration pond or an injection well, the cost of acquiring, capturing, stabilizing and treating source water, the cost of land and the cost of pumping. The cost of recharge mainly depends on local hydrogeological features of the aquifer that determine a technically suitable method to accomplish recharge. Recharge rates, both infiltration and injection, and quality of source water are the major factors that influence the cost of any aquifer recharge and storage facility. Little information exists on the actual cost of aquifer recharge and storage facilities in Australia and elsewhere. Some available Managed Aquifer Recharge cost data is local and situation specific, making cost comparison difficult across regions.

In this study, we use the annualized or levelised costs for estimating the cost of aquifer storage and recovery over 50 years with a $7 \%$ discount rate. Levelised cost is the constant level of revenue required each year to recover all the capital, operating and maintenance expenses over the life of the project divided by the annual volume of supply, expressed in \$/ML (Dillon et al., 2009).

\section{IRRIGATION WATER STORAGE SCENARIOS}

The study estimates all the relevant costs and benefits and compares net irrigation benefits under three different water storage scenarios which are: surface storage in farm dams, aquifer storage using pond infiltration, and aquifer storage using ASR or injection wells.

\subsection{On Farm Surface Storage, the Base Case}

In our Base case, net farm income is estimated when farmers continue with the existing water management practices and choose the option to store water in surface farm dams. Surface storages have significant evaporative losses and deep drainage losses. Cotton Catchment Communities (CRC) and other studies reported 35\%-45\% losses from surface farm dams annually-see Wigginton (2011) and Dalton et al. (2001). In this analysis, we assume $35 \%$ evaporative losses from the surface storage. Figure 1 outlines the total and net water available for irrigation in the base case. 
Arshad et al. 2013, Cost-Benefit Analysis of Farm Water Storage: Surface Storage versus Managed Aquifer Storage

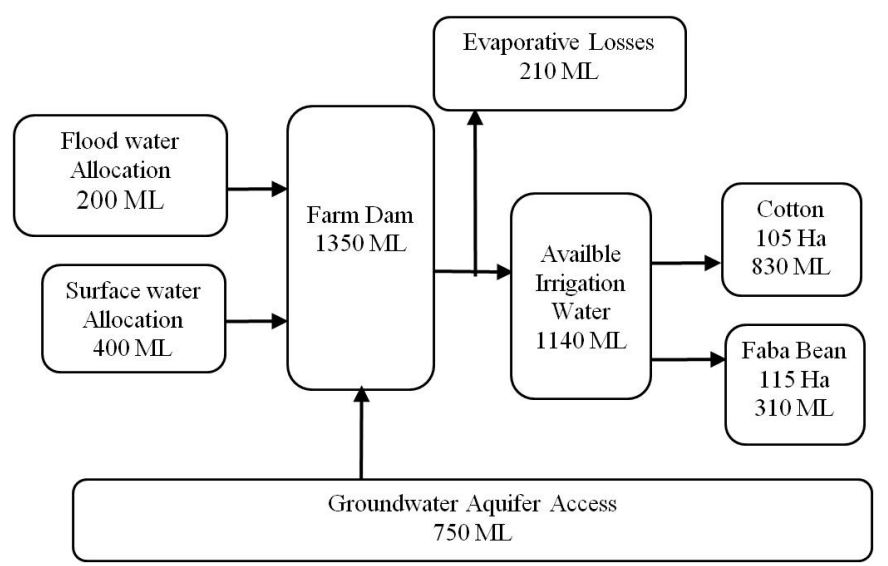

Figure 1. Water availability and storage for the Base case

In the Base case, cost includes the opportunity cost of lost water in evaporation and the forgone farm benefits. The maintenance cost of the existing farm infrastructure is only incidental and minimal, i.e. occasional repair of leaking pipes and minor earth works, thus such maintenance costs are not accounted for in the analysis. Annual lost income from evaporative losses is calculated as the net income in $\$ / \mathrm{ML}$ times the quantity of lost water annually in evaporation, shown in Table 2.

Table 2. Cost of Evaporative Losses

\begin{tabular}{|l|l|l|l|}
\hline \multicolumn{1}{|c|}{ Crop } & \multicolumn{1}{|c|}{$\begin{array}{c}\text { Evaporative } \\
\text { Losses (ML) }\end{array}$} & $\begin{array}{c}\text { Net Farm Income } \\
(\$ / M L)\end{array}$ & $\begin{array}{c}\text { Lost Farm } \\
\text { Income (AU\$) }\end{array}$ \\
\hline Cotton & 160 & 207 & 33,120 \\
\hline Faba bean & 50 & 277 & 13,850 \\
\hline Total & 210 & & 46,970 \\
\hline
\end{tabular}

In the Base case scenario, an irrigated land of 220 ha is considered, with cotton and faba rotations. The two crops have the highest margins per ML of water used. Net present value of farm benefits are estimated using an NPV function over 50 years with a 7\% interest rate and is reported in Section 5.

\subsection{Managed Aquifer Recharge and Storage with Infiltration ponds}

Aquifer storage can offer significant water savings by controlling evaporative losses. We consider an aquifer storage of $600 \mathrm{ML}$ of water through infiltration ponds. This will require new infrastructure and additional costs to store the water underground and pump it back when needed. The analysis assumes $15 \%$ losses $(90$ ML) during the aquifer recharge, storage and recovery processes, including evaporative losses following an earlier MAR study, Khan et al.(2008). With assumed 85\% recovery of the recharged water, some $120 \mathrm{ML}$ of additional groundwater water would be available compared to the Base case (Figure 2).

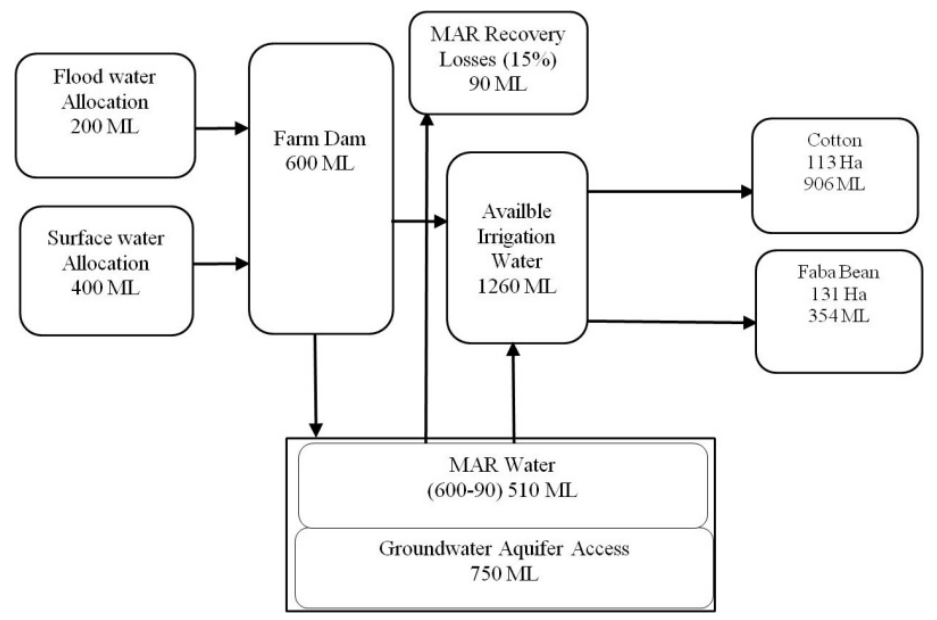

Figure 2. Water storage with managed aquifer recharge 
Arshad et al. 2013, Cost-Benefit Analysis of Farm Water Storage: Surface Storage versus Managed Aquifer Storage

With the additional water, farmers have a choice to irrigate additional land with cotton, faba bean or some combination of the two crops that yields the highest returns. Figure 3 provides and compares the capital, annual operation and maintenance and annualized costs of the three water storage options considered in the analysis. We consider an infiltration pond to recharge $600 \mathrm{ML}$ of water assuming 90 days of annual operation with infiltration rates of $0.5 \mathrm{~m} /$ day. This will require an infiltration basin of $120 \mathrm{~m} \times 120 \mathrm{~m}$ and $2 \mathrm{~m}$ deep. Such a pond can hold $28.8 \mathrm{ML}$ of water. Thus a single cycle will take four days to recharge $28.8 \mathrm{ML}$ at a rate of 7.20 ML/day. Recharge of $600 \mathrm{ML}$ can be achieved in about 83 days, round the year when recharge water is available. The costs are basically derived from Khan et al. (2008), Dillon et al.(2009) and Pyne (2010). For this analysis a $30 \%$ higher capital cost is used to account for the uncertainty due to soil heterogeneity. The cost of pond infiltration includes the capital cost of pond construction (AU\$168,400). The annual recurring cost (AU\$ 36,252) includes cost of maintenance ( $3 \%$ of the capital cost) and the cost of pumping water $(25$ $\$ / M L)$. The levelised cost of pond infiltration system is estimated as AU\$264/ML and the annualized cost as AU\$ 48,500, shown in Figure 3.

\subsection{Managed Aquifer Recharge and Storage with ASR}

When the hydrogeological conditions do not favour recharge through pond infiltration method, recharge can be accomplished alternatively using ASR method (injection wells). ASR can achieve injection rates of 8-12 ML/day per borehole (Pyne, 2010). The analysis assumes $85 \%$ recovery of the injected water (Khan et al., 2008). The cost of an ASR system includes the capital cost of well drilling and its construction, the cost of water treatment and the annual cost of maintenance and the cost of pumping water during recovery. The capital cost of an ASR system is adopted from Khan et al. (2008). For this study we consider a 30\% higher cost used by Khan et al. (2008) and adjusted it to the year 2013 by using a $2.4 \%$ inflation rate per annum for 5 years. The levelised cost of an ASR system is estimated as AU\$192/ML and the annualized cost as AU\$ 92, 000 (Figure 3). Farm benefits are estimated using an NPV function for 50 years and assuming a 7\% discount rate. Results are reported and discussed in Section 5.

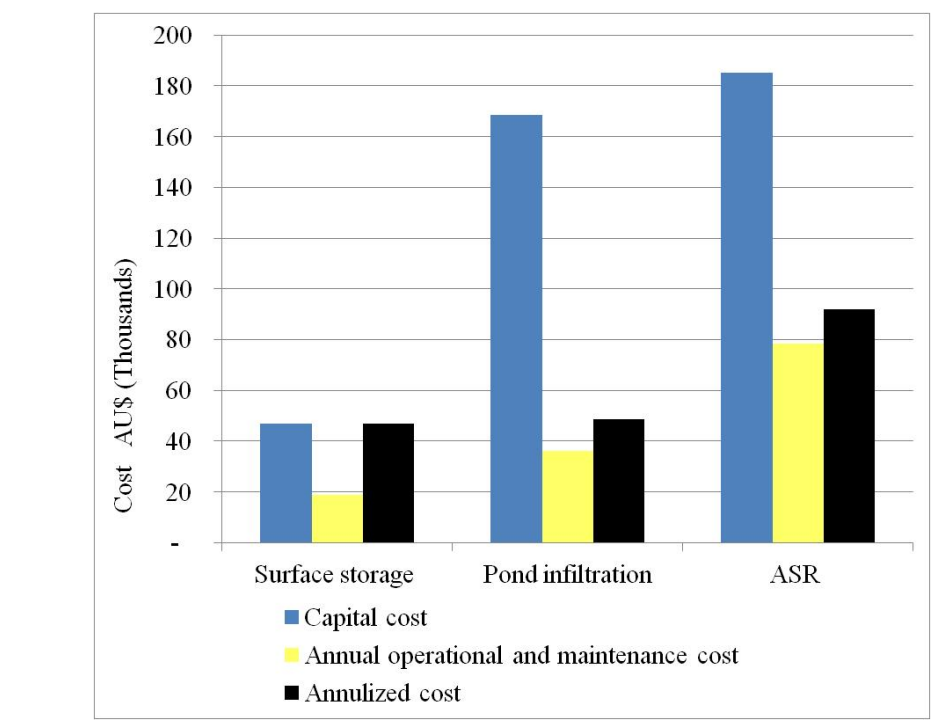

Figure 3. Costs of water storage options

Modified from Khan et al. (2008), Dillon et al. (2009) and Pyne (2010)

\section{RESULTS AND DISCUSSION}

Considering the three water storage and management options, this study compares the Net Present Values (NPV) of the two Aquifer storage methods with the Base case of surface water storage in farm dams. A long term trajectory of the difference of discounted costs and discounted benefits of the three water storage options is expressed as net present value. Figure 4 shows the NPVs of the three water storage options over 50 years. The results of the cost- benefit analysis indicate that aquifer storage is financially viable to implement in the lower Namoi. Aquifer storage will provide higher farm benefits than surface storage of irrigation water. Over the next 50 years, aquifer storage through the pond infiltration method will result in the highest farm benefits with an NPV of AU\$ 4.05 Million (M). Aquifer storage with ASR ranks second with an NPV 

Storage

of AU\$ $3.46 \mathrm{M}$ and surface storage in farm dams (Base case) ranks third with an NPV of AU\$ $3.26 \mathrm{M}$. Aquifer Storage of $600 \mathrm{ML}$ with a pond infiltration method will yield 24\%, and with the ASR method 6\%, higher benefits than surface storage. A single cotton irrigation farm of 1200 ha, adopting a Managed Aquifer Storage of $600 \mathrm{ML}$ annually, would bring an additional farm income of about AU $\$ 58,000$ with pond infiltration and AU $\$ 14,200$ with ASR compared to surface storage. Basin infiltration system is more economical than ASR and can be piloted in areas where river-aquifer connectivity exists; particularly in zones where the river system is losing to the aquifer. A pond infiltration system would be feasible to recharge unconfined shallow or semi confined aquifers. However, an ASR system would be needed to recharge deep aquifers and pockets with heavy clay contents, or areas with soil infiltration rates below $0.14 \mathrm{~m}$ per square $\mathrm{m}$ per day (Bouwer, 2002).

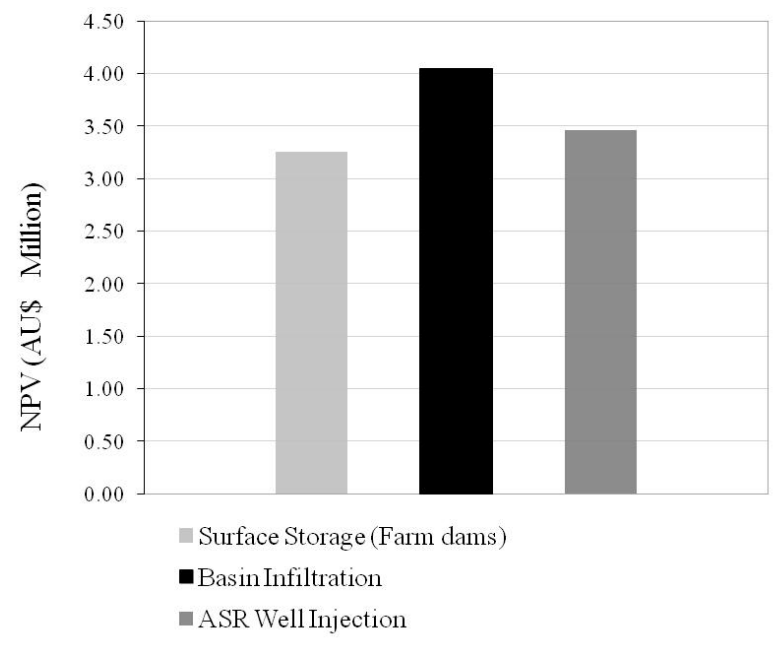

Figure 4. Net Present Value (NPV) of surface storage, pond infiltration and ASR options

Another important finding of this study is that constructing a new temporary storage of floodwater can be expensive for MAR. For example, construction of a new temporary storage will cost approximately AU\$ 3,000 per ML. On the majority of farms in the lower Namoi, temporary storage already exists as farm dams. On places where temporary storage is absent, it may render MAR uneconomical for agricultural purposes. Our preliminary analysis indicates that for MAR to be financially viable the maximum cost of aquifer storage, regardless of MAR method, should not exceed $500 \$ / M L$ to achieve the breakeven point that is, the point when the cost of aquifer storage is equal to the resulting farm benefits. Sensitivity analysis is performed on key variables, such as the infiltration rates, cost of pumping and cotton price. Infiltration rates and pumping costs are found less sensitive, while cotton price is, not surprisingly, found highly sensitive to the NPV. A $50 \%$ reduction in infiltration rates (Fig. 5 a) and a $25 \%$ increase in the cost of pumping (Fig. 5 b) do not significantly affect the NPV. However, a $10 \%$ and $25 \%$ reduction in the price of cotton renders a $27 \%$ and $78 \%$ reduction in the NPV respectively (Fig. 5 c).
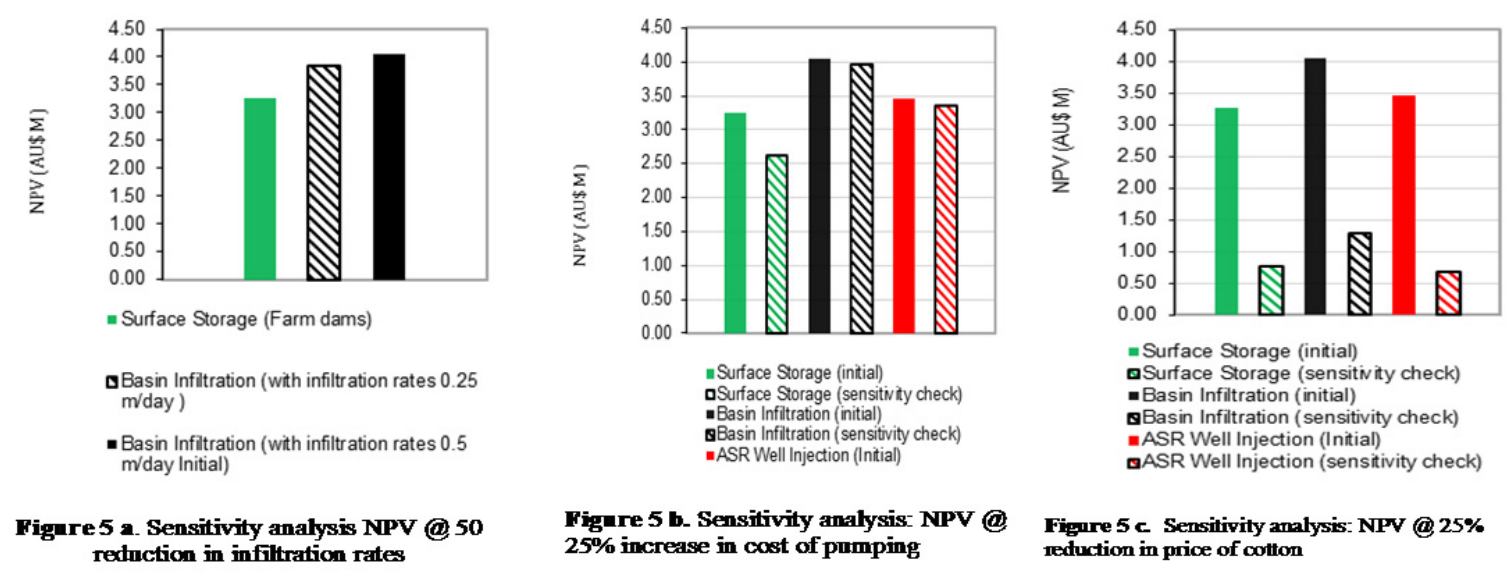
Arshad et al. 2013, Cost-Benefit Analysis of Farm Water Storage: Surface Storage versus Managed Aquifer Storage

\section{CONCLUSIONS}

In the lower Namoi irrigation area, the opportunity for aquifer storage can be advantageous for two reasons: a) under existing rules, large quantities of floodwater are available to harvest in wet periods and be stored underground; b) the existing on-farm storage dams sidesteps the need for building temporary storage of floodwater before recharging it underground. This would result in substantial savings. Preliminary findings of the cost-benefit analysis indicate that the economic impact of evaporative losses is significant in the lower Namoi. Aquifer storage is a cost effective option and financially viable when infiltration ponds are used as the method of recharge. Further, MAR is more attractive when temporary storage is already available as it is in the lower Namoi. Cost estimates of aquifer recharge are scarce, only found in consultancy reports of government funded projects, while itemized cost can only be obtained through combining several sources and field investigations. The current study is expected to guide farmers' decision making for rational investment in water storage infrastructure. The study realises that estimation of environmental costs and benefits is a knowledge gap and shall be a future research topic.

\section{REFERENCES}

Arshad, M., Jakeman, A. J., Kelly, B. F. J., Qureshi, M. E., Croke, B. F. W., Blakers, R. S., Ross, A. J., Curtis, A. \& Rawluk, A. (2012). Assessing the potential of Managed Aquifer Recharge: Preliminary hydrological findings from a scoping study in the lower Namoi Valley, Australia. In: Kulkarni, P. S., Mayilswami, C. ,Thangarajan, M. and \& Singh, V.P. (eds): Proceedings of the Fifth International Groundwater Conference on the Assessment and Management of Groundwater resources in hard rock systems with special reference to Basaltic terrain, Vol II,. Department of Geology, Maulana Azad College, Aurangabad, Maharashtra, India:,pp 58-70.

Bouwer, H. (2002). Artificial recharge of groundwater: Hydrogeology and egineering. Hydrogeology Journal, 10, 121-142.

Dalton, P., Raine, S. \& Broadfoot, K. (2001). Best management practices for maximising whole farm irrigation efficiency in the Australian cotton industry. Final report to the Cotton Research and Development Corporation, National Centre for Engineering in Agriculture Report, 179707.

Dillon, P., Pavelic, P., Page, D., Beringen, H. \& Ward, J. (2009). Managed Aquifer Recharge: An Introduction, Waterlines Series Report No.13, National Water Commission Canberra.

Khan, S., Mushtaq, S., Hanjra, M. A. \& Schaeffer, J. (2008). Estimating potential costs and gains from an aquifer storage and recovery program in Australia. Agricultural Water Management, 95, 477-488.

Murray Darling Basin Authority (2012). MDBA Basin Plan, a revised draft. Canberra.

Namoi Catchment Management Authority (2013). Availbe from http://www.namoi.cma.nsw.gov.au, accessed on January 25, 2013.

NSW Department of Primary Industries (2013). Summer crop gross margin budgets: Irrigated northern summer crop gross margins. DPI, NSW.

Powell, J. \& Scott, F. (2011). A representative irrigated farming system in the Lower Namoi Valley of NSW: An economic analysis. Economic Research Report.

Pyne, R. D. G. (2010). Aquifer Storage Recovery: Economics and recent technical advances in achieving ground water supply sustainability \& reliability through Managed Aquifer Recharge. Proceedings of the 7th Intentanational Symposium of Managed Aquifer Recharge ISMAR 7, 9-13 October 2010, Abu Dahbi. IAH.

Rawluk, A., Curtis, A., Sharp, E., Kelly, B., Jakeman, A., Ross, A., Arshad, M., Brodie, R., Pollino, C. \& Sinclair, D. (2012). Managed aquifer recharge in farming landscapes using large floods: an opportunity to improve outcomes for the Murray-Darling Basin? Australasian Journal of Environmental Management, vol. iFirst, pp. 1-15.

Smithson, A. (2009). Lower Namoi Groundwater Source: Groundwater Management Area 001, Groundwater Status Report 2008, NSW Department of Water and Energy, Sydney.

Wiggton, D. (2011). Measuring losses from on-farm water storages in the cotton industry, Proceedings of Irrigation 2011-New Horizons, Fresh Ideas Regional Conference and Exhibition. Irrigation Australia Ltd. 